\title{
References:
}

1. Про приватизацію державного та комунального майна : Закон України від 18 січня 2018 р. № 2269-VIII. Відомості Верховної Ради України. 2018. № 12. Ст. 68. URL: https://zakon.rada.gov.ua/laws/show/ 2269-19 (дата звернення: 26.10.2020).

2. Про захист економічної конкуренції : Закон України від 11 січня 2001 p. № 2210-III. Відомості Верховної Ради Украӥни. 2001. № 12. Ст. 64. URL: https://zakon.rada.gov.ua/laws/show/2210-14 (дата звернення: 26.10.2020).

3. Положення про порядок подання та розгляду заяв про попереднє отримання дозволу Антимонопольного комітету України на концентрацію суб'єктів господарювання : затв. розпорядженням Антимонопольного комітету України від 19 лютого 2002 р. № 33-p. URL: https://zakon.rada.gov.ua/laws/show/z0284-02 (дата звернення: 26.10.2020).

DOI https://doi.org/10.30525/978-9934-588-92-1-66

\section{НЕКОТОРЫЕ ПРОБЛЕМЫ ЗАЩИТЫ ПРАВ ПОТРЕБИТЕЛЕЙ ДИСТАНЦИОННЫХ БАНКОВСКИХ УСЛУГ}

\author{
Плотникова М. В. \\ кандидат юридических наук, \\ дочент кафедры международного, \\ европейского права и гражданско-правовых дисииплин \\ Сумского государственного университета \\ 2. Сумы, Украина
}

Деятельность по оказанию банковских услуг, как и других финансовых услуг, детально урегулирована правовыми нормами с целью защиты потребителей как менее защищенную сторону правоотношений. Законами Украины «О банках и банковской деятельности», «O платежных системах и переводе средств в Украине», «О финансовых услугах и государственном регулировании финансовых услуг» определены понятие банковских услуг и основные требования к субъектам, которые имеют право их оказывать. Подзаконное регулирование данной сферы осуществляется нормативно-правовыми актами Национального банка Украины. 
Развитие технологий в последние несколько десятилетий позволили банкам сделать значительно удобней для потребителя процесс получения банковских услуг. Речь идет, в том числе, о возможности получения банковских услуг дистанционно, например: получение информации о состоянии счета или блокировании операций через колцентр банка, осуществление банковских операций через приложение на мобильном телефоне клиента, через сайт банка или сайт платежной системы, банкомата или терминала самообслуживания.

Понятие дистанционного обслуживания определено в Инструкции о безналичных расчетах в Украине в национальной валюте [1]. Так, дистанционным обслуживанием является комплекс информационных услуг по счету клиента и осуществления операций по счету на основании дистанционных распоряжений клиента, которые передаются без посещения клиентом банка по заранее согласованному каналу доступа. Полного перечня способов оказывать дистанционные банковские услуги нормативно-правовые акты Национального банка Украины не содержат, указывается лишь, что дистанционное обслуживание счета клиент может осуществлять с помощью систем «клиент-банк», «клиент-Интернет-банк», «телефонный банкинг», «платежное приложение» и других систем дистанционного обслуживания. В Главе 10 Инструкции установлены особенности расчетов с помощью систем дистанционного обслуживания.

Важным моментом при проведении дистанционного обслуживания является идентификация клиента, способ которой выбирается в зависимости от типа получения дистанционной услуги (указание секретного слова для телефонного банкинга, ввод пин-кода и/или пароля, подтверждение через получение сообщений на телефон клиента и тому подобное). Однако, доступность дистанционного обслуживания для клиента создает угрозы для совершения в отношении него мошеннических действий.

В интернет-банкинге основной угрозой является фишинг. Это вид мошенничества, суть которого заключается в том, что пользователь по невнимательности открывает ссылку на ненастоящий сайт и вводит данные, необходимые для совершения банковской операции, с помощью которых мошенники могут получить доступ к средствам плательщика. Банки, как правило, проводят разъяснительную работу для клиентов, указывая на признаки фишинга, и призывают своих клиентов быть внимательными [2].

Фишинг стал угрозой и для клиентов, которые стремятся использовать мобильные приложения. Так, в 2018 году в Украине через Google Play распространялось приложение «Универсальный 270 
мобильный банкинг», которое позволяло клиентам ввести данные карт нескольких банков и осуществлять с ними банковские операции. Хотя, по сути, данное приложение было программой для кражи личных данных и денег клиентов [3]. В данной ситуации клиенты не могли предполагать, что становятся жертвами мошенников, ведь существуют приложения для мобильного банкинга отдельных банков, а также Apple Рау для проведения платежей с карт разных банков.

На практике в Украине порядок использования мобильного приложения для осуществления банковских операций не всегда определяется в договорах текущего счета, а установка мобильного приложения рекомендуется банком клиентам для удобства. Фактически именно при установке приложения клиенты соглашаются на условия предоставления дистанционных банковских услуг, принимая его условия, они дополняют существующие договорные отношения. Не смотря на то, что информация об официальном мобильном приложении каждого банка представлена на сайте финансового учреждения, существует риск того, что клиент станет использовать мошенническое мобильное приложение мобильного банкинга. Поэтому, на наш взгляд, необходимо больше внимания в нормативно-правовых актах Национального банка Украины уделить порядку использования мобильных приложений для дистанционного оказания банковских услуг с целью обеспечить защиту прав их потребителей.

\section{Литература:}

1. Інструкція про безготівкові розрахунки в Україні в національній валюті, затверджена Постановою Правління Національного банку України 21.01.2004 № 22. URL: https://zakon.rada.gov.ua/laws/show/z0377-04\#Text.

2. Рекомендації щодо захисту від фішингу. URL: https://ibank.procreditbank.com.ua/doc/phishing_ua.pdf.

3. ПриватБанк» знову повідомляе про шахрайський додаток «Універсальний мобільний банкінг». URL: https://www.unian.ua/ economics/finance/10040654-privatbank-znovu-povidomlyaye-proshahrayskiy-dodatok-universalniy-mobilniy-banking.html. 